\title{
Physiological Mapping of Local Inhibitory Inputs to the Hypothalamic Paraventricular Nucleus
}

\author{
Cherif Boudaba, Kriszta Szabó, and Jeffrey G. Tasker \\ Department of Cell and Molecular Biology, Tulane University, New Orleans, Louisiana 70118-5698
}

Local inhibitory synaptic inputs to neurons of the rat hypothalamic paraventricular nucleus (PVN) were studied by using glutamate microstimulation and conventional intracellular and whole-cell patch-clamp recordings in coronal, horizontal, and parasagittal slices of rat hypothalamus. PVN cells were classified as magnocellular or parvocellular neurons on the basis of electrophysiological and post hoc immunohistochemical analyses; GABA-producing neurons were localized with in situ hybridization. Glutamate microstimulation of different sites around the PVN evoked volleys of postsynaptic potentials in $43 \%$ of the PVN neurons tested. Some responses to stimulation at each site were blocked by bicuculline, suggesting that they were mediated by the activation of presynaptic GABA neurons. In the coronal plane, presynaptic inhibitory sites were located lateral to the PVN and ventral to the fornix, corresponding to the lateral hypothalamic area and the posterior bed nucleus of the stria terminalis (BNST). In the horizontal plane, presynaptic inhibitory sites were found rostral, lateral, and caudal to the nucleus, corresponding to parts of the anterior hypothalamic area, the posterior BNST, the medial preoptic area, and the dorsomedial hypothalamus. In the parasagittal plane, presynaptic inhibitory neurons were revealed at sites rostral and caudal to the nucleus, corresponding to the medial preoptic area and the dorsomedial hypothalamus, and in a site dorsal to the optic chiasm that included the suprachiasmatic nucleus. These presynaptic sites each contained GABA-producing neurons based on in situ hybridization with a glutamic acid decarboxylase riboprobe and together formed a three-dimensional ring around the PVN. Unexpectedly, both magnocellular and parvocellular neurons received inhibitory synaptic inputs from common sites.

Key words: brain slice; hypothalamus; inhibitory postsynaptic potential; paraventricular nucleus; magnocellular neuron; parvocellular neuron; hypophysiotropic; GABA; glutamic acid decarboxylase (GAD); in situ hybridization
Pulsatile hormone secretion, a common characteristic of neurosecretory systems of the hypothalamus, often is caused by synchronous burst generation among neurosecretory neurons. Several intrinsic and synaptic mechanisms can contribute to burst generation in hypothalamic neurons (Bourque and Renaud, 1990). However, the synchronization of bursting activity among individual neurosecretory cells (e.g., in oxytocin neurons or gonadotropin-releasing hormone cells) requires coordinated synaptic inputs to the individual cells, either through common synaptic inputs or through synaptic interconnectivity via local synaptic circuits.

Several anatomical and electrophysiological studies suggest that hypothalamic neuroendocrine cells are regulated by local synaptic circuits and that local circuits may contribute to patterned hormone secretion. A majority of the synaptic inputs to the paraventricular nucleus (PVN) seem to originate from local sources (Tribollet and Dreifuss, 1981; Kiss et al., 1983; Larsen et al., 1994). GABAergic inputs make up $\sim 50 \%$ of the synaptic inner-

\footnotetext{
Received May 6, 1996; revised Aug. 22, 1996; accepted Aug. 27, 1996.

This research was supported by grants from the Louisiana Board of Regents, the National Science Foundation (IBN-9315308), and the National Institute of Neurological Disorders and Stroke (NS31187). We thank Dr. A. G. Robinson for providing us with the neurophysin antibody, Dr. H. Gainer for the antibodies to oxytocin and vasopressin, and Dr. A. J. Tobin for his gift of GAD cDNAs. We are grateful to Drs. W. Armstrong, D. Poulain, D. Theodosis, and K. Muneoka for their critical evaluation of this manuscript and to Dr. A. Fáncsik and R. Dotson for their help with computer graphics.

Correspondence should be addressed to Dr. Jeffrey G. Tasker, Department of Cell and Molecular Biology, 2000 Percival Stern Hall, Tulane University, New Orleans, LA 70118-5698.

Cherif Boudaba's permanent address: Institut des Sciences de la Nature, USTHB, BP 39 Dar El Beida, Algiers, Algeria.

Copyright (C) 1996 Society for Neuroscience $0270-6474 / 96 / 167151-10 \$ 05.00 / 0$
}

vation of PVN neurons (Decavel and van den Pol, 1990), and a significant proportion of this GABAergic innervation derives from regions intrinsic to the hypothalamus (Roland and Sawchenko, 1993). A recent electrophysiological study showed that the vast majority of the local synaptic inputs to PVN neurons are GABAergic (Tasker and Dudek, 1993).

The PVN is composed of two general populations of neurons, the magnocellular neurons, which project to the posterior pituitary, and the parvocellular neurons, which project to the anterior pituitary and to other areas of the brain and spinal cord (Swanson and Sawchenko, 1983). The physiological study of synaptic inputs to the PVN is complicated by the heterogeneity of cell types in the nucleus. However, magnocellular and parvocellular neurons of the PVN can be distinguished according to certain electrophysiological criteria, allowing for a reliable preliminary assessment of cellular identity during recordings (Hoffman et al., 1991; Tasker and Dudek, 1991). The most salient characteristic of magnocellular neurons is their expression of a robust transient $\mathrm{K}^{+}$current (Bourque, 1988; Tasker and Dudek, 1991). In contrast, parvocellular neurons usually do not show a detectable transient $\mathrm{K}^{+}$ current, but most generate a $\mathrm{Ca}^{2+}$-dependent, low threshold potential (Tasker and Dudek, 1991). Among magnocellular neurons, vasopressinergic cells sometimes can be distinguished from oxytocinergic cells by their phasic bursting activity (Poulain and Wakerley, 1982). This preliminary electrophysiological classification, combined with subsequent immunohistochemical labeling of recorded and dye-injected cells, provides a reliable means of identifying magnocellular and parvocellular neurons of the PVN (Hoffman et al., 1991). 
The purposes of the present study were (1) to determine whether local inhibitory neurons projecting to the PVN are organized topographically in distinct regions in the hypothalamus and (2) to test the hypothesis that local inhibitory inputs to magnocellular and parvocellular neurons of the PVN originate from different presynaptic sites. Using glutamate microstimulation and conventional intracellular and whole-cell patch-clamp recordings from PVN neurons in three slice planes (i.e., coronal, horizontal, and parasagittal), we found presynaptic inhibitory sites distributed in two relatively discrete zones, one extending around the PVN laterally and the other ventral to the PVN at the base of the hypothalamus. Both magnocellular and parvocellular neurons received inhibitory synaptic inputs from each presynaptic zone.

Preliminary reports of these data have been presented previously (Tasker, 1993; Boudaba et al., 1995).

\section{MATERIALS AND METHODS}

Slice preparation. Male Sprague Dawley rats (Charles River, Wilmington, MA) were anesthetized deeply with Nembutal $(0.1 \mathrm{ml} / 100 \mathrm{gm}$ body weight) and decapitated. The brain was removed quickly and gently from the cranial cavity and immersed in cooled $\left(1-2^{\circ} \mathrm{C}\right)$, aerated $\left(95 \% \mathrm{O}_{2} / 5 \%\right.$ $\mathrm{CO}_{2}$ ) artificial cerebrospinal fluid (aCSF). The composition of the aCSF was (in mM): $124 \mathrm{NaCl}, 3 \mathrm{KCl}, 1.3 \mathrm{MgSO}_{4}, 1.4 \mathrm{NaH}_{2} \mathrm{PO}_{4}, 11$ Glucose, 5 HEPES, and $2.4 \mathrm{CaCl}_{2}$. The $\mathrm{pH}$ of the aCSF was adjusted to $7.2-7.4$ with $\mathrm{NaOH}$. In some experiments the concentrations of $\mathrm{MgSO}_{4}$ and $\mathrm{CaCl}_{2}$ were increased to $4 \mathrm{~mm}$ to reduce the spontaneous synaptic activity of the recorded cells. The hypothalamus was blocked with a razor, and hypothalamic slices $(400-500 \mu \mathrm{m})$ were sectioned in the coronal, horizontal, and parasagittal planes with a vibrating microtome (WPI, Sarasota, FL). One or two slices containing the PVN were identified in the different planes, according to Paxinos and Watson (1986). The slices were transferred immediately to a ramp-style interface recording chamber in which they were perfused with aCSF maintained at $32-34^{\circ} \mathrm{C}$ and aerated with humidified $95 \% \mathrm{O}_{2} / 5 \% \mathrm{CO}_{2}$. In some cases, a second slice was stored submerged in an aerated holding chamber at room temperature until experiments in the first slice were completed. All slices were allowed to equilibrate in the recording chamber for $\geq 1 \mathrm{hr}$ before recordings were started.

Electrophysiological methods. Conventional intracellular microelectrodes were made from microfilament glass capillaries $[0.6 \mathrm{~mm}$ inner diameter (i.d.), $1.0 \mathrm{~mm}$ outer diameter (o.d.); WPI, Sarasota, FL], and patch pipettes were pulled from borosilicate glass $(1.65 \mathrm{~mm}$ o.d., 1.2 mm i.d.; Garner Glass, Claremont, CA) with a Flaming/Brown micropipette puller (Sutter Instruments, Novato, CA). Microelectrodes were filled with $2 \mathrm{M} \mathrm{KCl}$ or $2 \mathrm{M}$ potassium acetate. Potassium chloride was used in most conventional intracellular recordings to shift $E_{\mathrm{Cl}}$ positive to increase the $\mathrm{Cl}^{-}$driving force, resulting in reversed IPSPs that were larger and easier to detect; the percentage of cells that responded synaptically to glutamate microstimulation increased by $20-30 \%$ when $\mathrm{KCl}$ was used as the microelectrode electrolyte instead of potassium acetate (our unpublished observation). Patch pipettes were filled with a solution containing (in mM): 120 potassium gluconate, 10 HEPES, 1 $\mathrm{NaCl}, 1 \mathrm{CaCl}_{2}, 1 \mathrm{MgCl}_{2}, 2 \mathrm{Mg}$-ATP, $0.3 \mathrm{Na}$-GTP, and 10 EGTA; $\mathrm{HH}$ was adjusted to $7.2-7.4$ with $\mathrm{KOH}$.

The slice was transilluminated, and the electrode was positioned in the PVN under visual guidance with a dissecting microscope. The electrode was lowered through the slice by $2-4 \mu \mathrm{m}$ steps with a piezoelectric microdrive (Nanostepper, Adams \& List, Westbury, NY). Current-clamp recordings were performed with an Axoclamp 2A amplifier (Axon Instruments, Foster city, CA). Data were digitized on-line with a Digidata 1200 interface and pClamp 6.1 software (Axon) and stored on videotape for off-line analysis. Voltage and current traces were monitored continuously on a digital storage oscilloscope (Hitachi, Tokyo, Japan).

Biocytin was added to microelectrodes $(1 \%)$ and to patch pipettes $(0.3-0.5 \%)$ as an intracellular marker. The biocytin leaked into the recorded cells during the recordings and was iontophoresed intracellularly at the end of experiments by passing negative current pulses $(-250$ $\mathrm{pA}, 250 \mathrm{msec}, 2 \mathrm{~Hz}$ ) for 5-10 min.

Drug application. Using a patch pipette with a tip inner diameter of 5-10 $\mu \mathrm{m}$, glutamate microdrops $(10-20 \mathrm{mM})$ were applied on the surface of slices by pressure with a picospritzer (General Valve, Fairfield, NJ). The glutamate pipette was positioned with a hydraulic micromanipulator for fine control, and glutamate microdrops were applied under visual control at two or more sites on the slice whenever possible. Janus green $(0.1 \%)$ was added to the glutamate solution to map the location and to monitor the spread of the glutamate microdrops. Glutamate drops measured $\sim 200-250 \mu \mathrm{m}$ in diameter after radiating on the surface of the slice. The approximate positions of glutamate microapplication sites were mapped by eye, on the basis of visual landmarks, onto schematic diagrams of the hypothalamus in the coronal, horizontal, and parasagittal planes, according to Paxinos and Watson (1986) and Swanson (1992).

Bicuculline methiodide was added to the bath medium $(10-50 \mu \mathrm{M})$ to block $\mathrm{GABA}_{\mathrm{A}}$ receptor-mediated IPSPs. Bicuculline methiodide application was used to differentiate EPSPs from reversed IPSPs in some recordings performed with $\mathrm{KCl}$-filled microelectrodes.

Biocytin histology and peptide immunohistochemistry. After experiments, slices were removed from the recording chamber and fixed overnight in $4 \%$ paraformaldehyde in $0.1 \mathrm{~m}$ PBS. Then they were sectioned on a freezing microtome $(15-20 \mu \mathrm{m})$, and the biocytin-injected cells were labeled by incubating the slices for $4 \mathrm{hr}$ in streptavidin-conjugated 7-amino-4-methylcoumarin-3-acetic acid (AMCA, Molecular Probes, Eugene, OR). The AMCA was diluted (1:300) in $0.1 \mathrm{~m}$ PBS containing $1 \%$ Triton X-100. Sections were examined under a microscope equipped with epifluorescence by using a UV/420K filter combination to detect the presence of biocytin-filled, AMCA-labeled neurons.

Sections containing the AMCA-labeled cells were placed in $2 \%$ normal sheep serum in $0.1 \mathrm{M}$ PBS for $15 \mathrm{~min}$. To determine whether the stained cells were magnocellular or parvocellular neurons, we used a primary polyclonal antibody generated in rabbit against both oxytocin and vasopressin-associated neurophysins of the rat (RN-4, 9/10/73), which was obtained from Dr. A.G. Robinson, University of Pittsburgh (Seif et al., 1977). This general neurophysin antibody labels mainly magnocellular neurons under normal conditions (i.e., in rats that have not been subjected to adrenalectomy) and was selected to distinguish between PVN magnocellular and parvocellular neurons (Hoffman et al., 1991). Slices were incubated in the general neurophysin antiserum at a concentration of 1:10,000 in $0.1 \mathrm{M}$ PBS plus $1 \%$ normal sheep serum and $0.2 \% \mathrm{Na}$ azide for $36 \mathrm{hr}$ at $4^{\circ} \mathrm{C}$. In some cases in which the recorded cells were classified electrophysiologically as magnocellular neurons and recovered in two serial sections after biocytin labeling, polyclonal antibodies selective for oxytocin (VA-10) and vasopressin (VA-4), provided by Dr. H. Gainer (National Institutes of Health, Bethesda, MD) (Altstein et al., 1988), were used on separate sections. The oxytocin and vasopressin antisera were applied at concentrations of 1:800 and 1:1000, respectively, in $0.1 \mathrm{M}$ PBS plus $1 \%$ normal sheep serum and $0.2 \% \mathrm{Na}$ azide for $36 \mathrm{hr}$ at $4{ }^{\circ} \mathrm{C}$. After treatment with the primary antibody, sections were rinsed with 0.1 M PBS, incubated for $1 \mathrm{hr}$ in a goat anti-rabbit secondary antibody conjugated with fluorescein isothiocyanate (FITC, 1:100; Vector Labs, Burlingame, CA), and rinsed again in 0.1 M PBS. Then they were mounted and coverslipped with Vectashield antifading mounting medium (Vector Labs) and examined under epifluorescence for neurophysin, oxytocin, or vasopressin immunoreactivity by using a B/515W filter combination for FITC. Double labeling with AMCA and FITC was detected by switching from one fluorescence filter combination to the other.

The oxytocin and vasopressin antibodies were tested for cross-reactivity by using preadsorption controls. No immunostaining was observed when the oxytocin antibody was preadsorbed overnight at $4^{\circ} \mathrm{C}$ with oxytocin $\left(10^{-6}-10^{-4} \mathrm{M}\right)$ and when the vasopressin antibody was preadsorbed with vasopressin $\left(10^{-6}-10^{-4} \mathrm{M}\right)$. No decrement in the immunolabeling was apparent when the oxytocin antibody was preincubated with vasopressin $\left(10^{-6}-10^{-4} \mathrm{M}\right)$ or when the vasopressin antibody was preincubated with oxytocin $\left(10^{-6}-10^{-4} \mathrm{M}\right)$. The oxytocin antibody did not label neurons in the suprachiasmatic nucleus, which contains only vasopressin-expressing cells, and the vasopressin antibody did not label cells in the anterior commissural nucleus, which contains exclusively oxytocin neurons, thus providing further empirical evidence for the specificity of the two antibodies.

In situ hybridization histology. Putative GABA-producing neurons in the hypothalamus were labeled by in situ hybridization with a nonradioactive riboprobe for glutamic acid decarboxylase (GAD) mRNA, according to a slight modification of the technique described by Esclapez et al. (1993). Briefly, nonradioactive sense and antisense RNA probes were transcribed from rat glutamic acid decarboxylase 65 (GAD65) cDNA generously provided by Dr. A. J. Tobin (UCLA, Los Angeles, CA). The GAD65 cDNA was inserted into the pBluescript transcription vector (Stratagene, La Jolla, CA) for production of sense and antisense probes. The plasmids containing the GAD65 inserts were linearized with HindIII 
and transcribed with the T3 RNA polymerase in the presence of digoxygenin-11-UTP for antisense probe production or were linearized with $X b a \mathrm{I}$ and transcribed with $\mathrm{T} 7$ for sense probe production, according to the prescribed methods of a nonradioactive RNA labeling kit (Boehringer Mannheim, Indianapolis, IN). The GAD65 cDNA has been found to hybridize selectively to a cellular mRNA of $5.7 \mathrm{~kb}$ (Erlander et al., 1991).

Slices were prepared as for electrophysiological experiments but were fixed in MEMFA [0.1\% 4-morpholinepropanesulfonic acid (MOPS), 2 mM EGTA, $1 \mathrm{~mm} \mathrm{MgSO}_{4}$, and $3.7 \%$ formaldehyde] at $4{ }^{\circ} \mathrm{C}$ overnight. Then they were sectioned at $50 \mu \mathrm{m}$ on a freezing microtome and collected as free-floating sections. Sections were rinsed three times in $0.1 \mathrm{M}$ PBS with $0.1 \%$ Tween 20 for 5 min each and pretreated with the following solutions: once in PBS with $1 \mu \mathrm{g} / \mathrm{ml}$ proteinase $\mathrm{K}$ for $10 \mathrm{~min}$, twice in 0.1 $\mathrm{M}$ triethanolamine for $5 \mathrm{~min}$ each, and once in $0.1 \mathrm{M}$ triethanolamine with $5 \mu \mathrm{l}$ of acetic acid for $10 \mathrm{~min}$, followed by two washes in PBS for $5 \mathrm{~min}$ each. The sections were refixed in $4 \%$ paraformaldehyde for $20 \mathrm{~min}$, rinsed four times in $0.1 \mathrm{M}$ PBS for $5 \mathrm{~min}$ each and a fifth time with the addition of $0.5 \mathrm{ml}$ of prehybridization solution, and incubated in prehybridization solution containing $50 \%$ formamide, $5 \times$ sodium citrate solution (SSC: $150 \mathrm{~mm} \mathrm{NaCl}$ and $15 \mathrm{~mm}$ Na citrate, pH 7.4), 5 mm EDTA, $1 \times$ Denhardt's solution, $100 \mu \mathrm{g} / \mathrm{ml}$ heparin, $0.1 \%$ Tween 20, 1\% CHAPS, and $1 \mathrm{mg} / \mathrm{ml}$ yeast RNA. Then the sections were incubated overnight at $60^{\circ} \mathrm{C}$ in the hybridization buffer, consisting of the prehybridization solution with $1 \mu \mathrm{g} / \mathrm{ml}$ digoxygenin-labeled antisense probe; digoxygeninlabeled sense probe was used as a control. After hybridization, the sections were washed in the prehybridization buffer for $10 \mathrm{~min}$ at $60^{\circ} \mathrm{C}$, followed by washes in 1:1 concentrations of prehybridization buffer and $2 \times \mathrm{SSC}$ for $10 \mathrm{~min}$ at $60^{\circ} \mathrm{C}$, and $1: 3$ concentrations of prehybridization buffer and $2 \times \mathrm{SSC}$ for $10 \mathrm{~min}$ at $37^{\circ} \mathrm{C}$. They were washed twice in $2 \times \mathrm{SSC}$ for $20 \mathrm{~min}$ each at $37^{\circ} \mathrm{C}$ and twice in $0.2 \times \mathrm{SSC}$ for $30 \mathrm{~min}$ each at $60^{\circ} \mathrm{C}$. Before immunodetection of the riboprobe, the sections were washed in $3: 1,2: 2,1: 3$, and $0: 1$ concentrations of $0.2 \times$ SSC and TNT $(150 \mathrm{mM} \mathrm{NaCl}$, $100 \mathrm{~mm}$ Tris $\mathrm{HCl}$, and $0.1 \%$ Tween $20, \mathrm{pH} 7.5$ ) for $10 \mathrm{~min}$ each at room temperature. The RNA hybrids were labeled by a nucleic acid detection kit (Boehringer Mannheim), consisting of a $2 \mathrm{hr}$ wash in TNT containing $0.02 \%$ blocking reagent and $20 \%$ normal sheep serum, followed by overnight incubation in the same TNT solution containing alkaline phosphatase-conjugated antibodies to digoxigenin at a 1:5000 dilution. After washes in TNT, the sections were treated with the chromogen solution containing $45 \mu \mathrm{l}$ of nitro blue tetrazolium $(75 \mathrm{mg} / \mathrm{ml}$ in $70 \%$ dimethylformamide), $35 \mu$ l of 5-bromo-4-chloro-3-indolyl phosphate (50 $\mathrm{mg} / \mathrm{ml}$ in $100 \%$ dimethylformamide), and $2.4 \mathrm{mg}$ of levamisole in $10 \mathrm{ml}$ of buffer $\left(100 \mathrm{~mm} \mathrm{NaCl}, 50 \mathrm{mM} \mathrm{MgCl}_{2}\right.$, and $100 \mathrm{mM}$ Tris $\left.\mathrm{HCl}\right)$. The sections were mounted on gelatin-coated slides, air dried, and coverslipped in Vectashield mounting medium (Vector Labs). Labeled mRNA was found after in situ hybridization with the antisense probe but not after hybridization with the digoxygenin-labeled sense riboprobe. No labeling was found when the digoxygenin-labeled probes were omitted from the hybridization solution as a control.

Sections labeled with immunohistochemical and hybridization histochemical methods were photographed with a $35 \mathrm{~mm}$ camera with 200 ASA color film or on a video camera. Images were digitized at 72-320 dpi and processed by graphics software (Adobe Photoshop, Aldus Photostyler, and Coreldraw).

\section{RESULTS}

In total, 139 neurons were recorded in coronal $(n=36)$, horizontal $(n=65)$, and parasagittal $(n=38)$ slices of the rat hypothalamic PVN. The mean input resistance of cells recorded with patch electrodes was $662 \pm 52 \mathrm{M} \Omega(n=20, \mathrm{SEM})$ and that of neurons recorded with conventional microelectrodes was $279 \pm$ $13 \mathrm{M} \Omega(n=101)$. The mean membrane potential (uncorrected for junction potential) was $-55 \pm 1 \mathrm{mV}(n=113)$, and the mean spike amplitude (threshold to the peak) was $66 \pm 1 \mathrm{mV}(n=107)$.

\section{Electrophysiological classification}

All recorded cells were classified on the basis of their intrinsic electrical properties as putative magnocellular or putative parvocellular neurons (Hoffman et al., 1991; Tasker and Dudek, 1991). Thus, 48 cells were classified as putative magnocellular neurons, because they showed evidence of a prominent transient $\mathrm{K}^{+}$cur- rent; five of these cells were identified as putative vasopressinergic magnocellular neurons, because they showed a phasic bursting activity (Poulain and Wakerley, 1982). Ninety-one cells were classified as putative parvocellular neurons on the basis of the absence of a detectable transient $\mathrm{K}^{+}$current and/or the presence of a low threshold potential (Tasker and Dudek, 1991).

\section{Anatomical identification}

Of the 139 cells recorded and injected with biocytin, 53 neurons were recovered after biocytin histochemistry and immunohistochemical treatment with antibodies to oxytocin, vasopressin, or general neurophysin. Among the 48 cells classified as putative magnocellular neurons from their electrophysiology, 20 were located within the PVN and immunohistochemically labeled for neurophysin $(n=14)$, oxytocin $(n=4)$, or vasopressin $(n=2$; Fig. $1)$. Of the 91 cells classified electrophysiologically as parvocellular neurons, 25 were located within the PVN and were neurophysin negative (Fig. 1). Three cells classified electrophysiologically as magnocellular neurons were neurophysin negative or negative for both oxytocin and vasopressin, and three cells classified as parvocellular were neurophysin positive. Although it is not possible to assign an exact success rate because of false positive and negative immunohistochemical labeling, these data suggest that there was a maximum margin of error of $11-13 \%$ in our electrophysiological classification. Two putative parvocellular neurons were neurophysin negative and located outside the PVN.

\section{Direct activation by glutamate}

In all, 98 of 139 neurons tested with glutamate drops showed a sustained membrane depolarization, which often generated a train of inactivating action potentials (Tasker and Dudek, 1993) at one or more application sites. Sustained depolarizations usually were observed when the glutamate microdrops were applied in close proximity to the recorded neurons. These depolarizations were seen in putative magnocellular and parvocellular neurons (Tasker and Dudek, 1991) and probably were attributable to the direct activation by glutamate of the dendrites or the soma of the recorded cells.

\section{Glutamate-evoked synaptic activation}

To test the hypothesis that PVN-projecting GABA neurons are topographically organized in perinuclear zones and that these presynaptic zones differ for magnocellular and parvocellular neurons, we applied glutamate microdrops $(10-20 \mathrm{~mm})$ around the PVN in coronal, horizontal, and parasagittal slices. Whenever possible, glutamate was dropped at more than one position and usually at several positions in the slice. The spread of the glutamate microdrops on the surface of the slice was monitored with Janus green and measured between 200 and $250 \mu \mathrm{m}$ in diameter. Glutamate microdrops applied at some sites in the slice never evoked PSPs, whereas glutamate microstimulation at other sites elicited synaptic responses in 10-60\% of the cells tested. The synaptic responses consisted of volleys of PSPs that occurred after a latency ranging from 0.2 to $9 \mathrm{sec}$ and that lasted from 3 to $100 \mathrm{sec}$ (Fig. 2).

A total of 60 of 139 neurons tested (43\%) - 20 magnocellular neurons and 40 parvocellular neurons - generated PSPs at resting membrane potential in response to glutamate microdrops applied at different sites around the PVN. Approximately $42 \%$ of the putative magnocellular neurons (20/48) and $44 \%$ of the putative parvocellular neurons (40/91) tested responded synaptically to glutamate microdrops applied in one or more positions in the slice. The synaptic responses in a total of 19 of the 60 responsive neurons, including 8 magnocellular and 11 parvocellular, were 

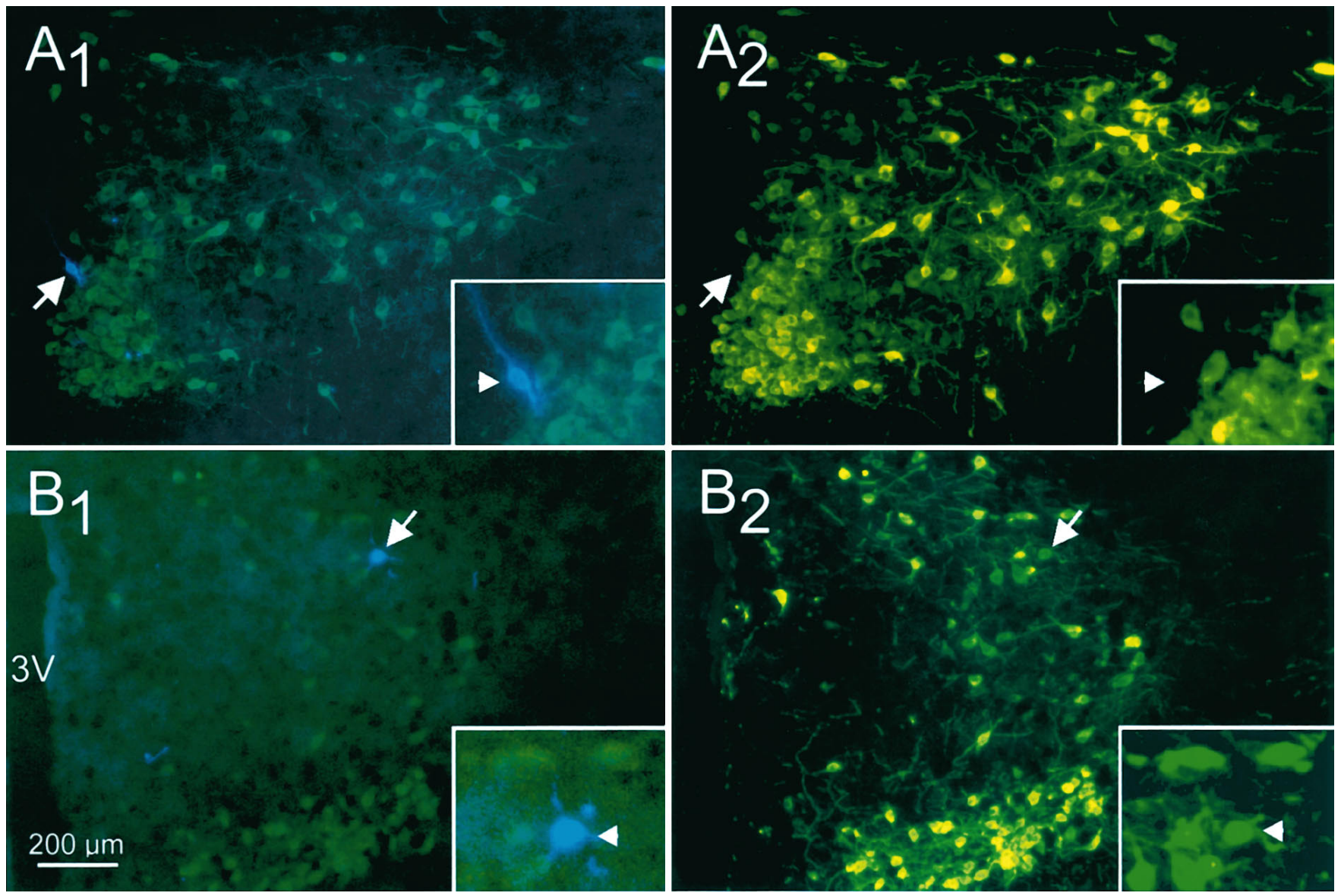

Figure 1. Immunohistochemical identification of neurons recorded in the PVN. Biocytin-labeled cells were visualized under the blue AMCA filter combination $(A 1, B 1)$, and cells stained immunohistochemically were examined under fluorescein filters $(A 2, B 2)$. The FITC fluorescence can be detected with the blue filter combination, but the AMCA is not detectable under the fluorescein filters. $A$, A PVN cell classified as a putative parvocellular neuron on the basis of its electrical properties was labeled with the intracellular biocytin/AMCA marker (A1); this cell was negative for the FITC neurophysin immunolabel (A2), confirming that it was a parvocellular neuron. $B$, A PVN cell classified electrophysiologically as a magnocellular neuron was double-labeled with the intracellular biocytin/AMCA label (B1) and with the FITC immunolabel for oxytocin (B2), indicating that it was an oxytocinergic magnocellular neuron. Sections in $A$ and $B$ were taken from horizontal slices. Insets show the areas containing the biocytin-labeled cells (arrows) enlarged twofold. $3 \mathrm{~V}$, Third ventricle.

identified positively as inhibitory by their hyperpolarizing orientation or their sensitivity to bicuculline. The glutamate-evoked PSPs were suppressed or blocked by bicuculline $(10-50 \mu \mathrm{M})$ in 10 of 11 cells tested, confirming that they were GABA-mediated IPSPs (Fig. 2).

\section{Topographic mapping of local presynaptic neurons}

A total of 12 of 36 neurons tested, 2 putative magnocellular and 10 putative parvocellular neurons, responded synaptically to glutamate microdrops in coronal slices. Three of the responsive neurons were verified immunohistochemically as PVN parvocellular neurons. The glutamate-evoked PSPs were confirmed as IPSPs in six cells (Table 1). In the coronal plane, positions in which glutamate microapplication elicited PSPs in PVN neurons were concentrated in a region lateral to the nucleus and ventral to the fornix (Fig. 3), corresponding to the anterior hypothalamic nucleus of Swanson (1992).

Neurons that expressed GAD65 mRNA were found throughout the coronal plane of the basal forebrain that included the PVN but were concentrated most heavily in the zona incerta and the anterior hypothalamic area (Fig. $4 A$ ). The PVN contained scattered GAD65 mRNA-containing neurons. A moderate density of GAD65 mRNA-containing neurons was found in the area ven- trolateral to the PVN (Fig. 4B), corresponding to the presynaptic inhibitory site revealed by glutamate microstimulation.

In horizontal slices, glutamate microdrops elicited synaptic responses in 26 of 65 recorded neurons, of which 7 were putative magnocellular and 19 were putative parvocellular neurons (Table 1). Synaptic responses were elicited with glutamate microstimulation applied at sites rostral and lateral to the PVN, flanking the fornix, as well as at a third site caudal to the nucleus (Fig. 5). With glutamate microapplication rostral to the PVN, 24 of 63 neurons $(38 \%)$ showed an increase in PSPs. The synaptic responses were identified as inhibitory in six of these cells. Glutamate microapplication lateral to the nucleus (caudal to the fornix) elicited an increase in PSPs in 7 of 42 PVN neurons (17\%), six of which also were activated by glutamate microdrops in the rostral position. Two of these responses were confirmed as inhibitory. Glutamate microdrops applied caudal to the PVN elicited synaptic responses in 3 of 31 neurons (10\%), two of which also responded to glutamate microapplication in the other two positions. A total of six neurons recorded in horizontal slices responded synaptically to glutamate microstimulation in two or more positions. Seven responsive cells ( 2 magnocellular and 5 parvocellular neurons) were identified immunohistochemically in horizontal slices. 


\section{CONTROL}

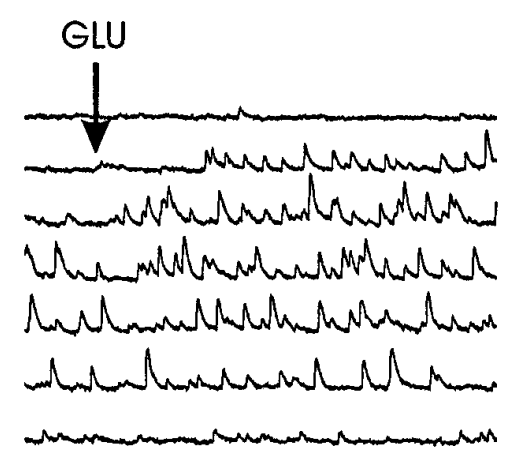

$10 \mu \mathrm{MBIC}$

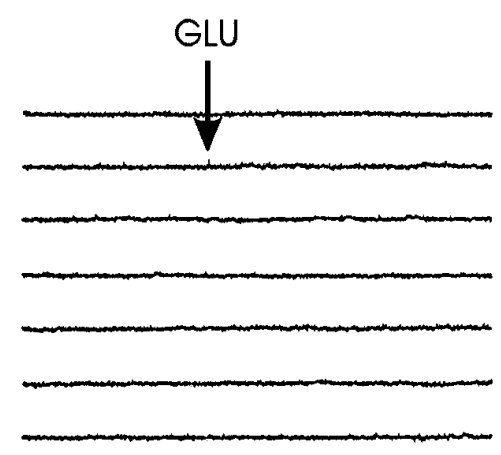

WASH (25 min)

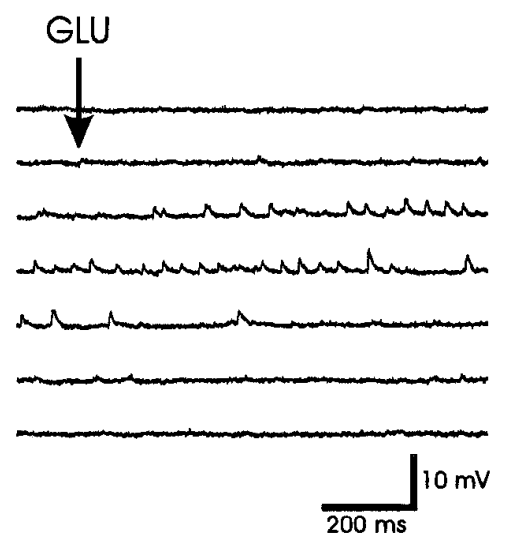

Figure 2. Glutamate-evoked IPSPs. Left, Glutamate microstimulation $(G L U)$ at a position ventral to the fornix elicited reversed IPSPs in a PVN

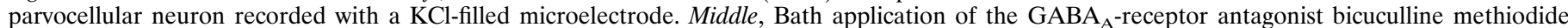
$(B I C)$ for 15 min completely blocked the effect of glutamate microapplication at the same site and with the same application parameters. Right, Partial recovery of the glutamate-evoked IPSPs was seen after $25 \mathrm{~min}$ of washout of the bicuculline. The membrane potential was held at $-105 \mathrm{mV}$ with negative current injection.

\section{Table 1. Distribution of synaptic responses according to PVN cell type, slice plane, and stimulation site}

\begin{tabular}{|c|c|c|c|c|c|c|c|}
\hline \multirow{2}{*}{$\begin{array}{l}\text { Plane } \\
\text { Cell type }\end{array}$} & \multirow{2}{*}{$\frac{\text { Coronal }}{\text { Ventrolateral }}$} & \multicolumn{3}{|c|}{ Horizontal } & \multicolumn{3}{|c|}{ Parasagittal } \\
\hline & & Rostral & Lateral & Caudal & Rostral & Ventral & Caudal \\
\hline Magnocellular & $2 / 12$ & $7 / 21$ & $2 / 14$ & $0 / 9$ & $3 / 10$ & $2 / 7$ & $8 / 12$ \\
\hline \multirow[t]{2}{*}{ Parvocellular } & $10 / 24$ & $17 / 42$ & $5 / 28$ & $3 / 22$ & $4 / 14$ & $4 / 11$ & $7 / 13$ \\
\hline & (6) & (3) & (1) & & & & (1) \\
\hline Total & $12 / 36$ & $24 / 63$ & $7 / 42$ & $3 / 31$ & $7 / 24$ & $6 / 18$ & $15 / 25$ \\
\hline
\end{tabular}

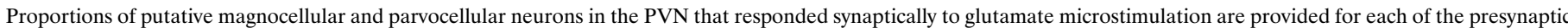

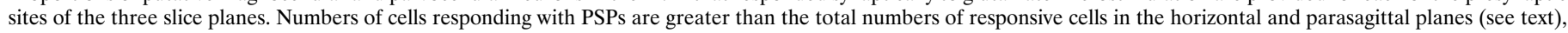
because some cells responded to glutamate microstimulation at more than one site. Numbers of cells in which confirmed IPSPs were recorded are given in parentheses.

The regions concentrating presynaptic inhibitory neurons in the horizontal plane included the medial part of the posterior bed nucleus of the stria terminalis, the medial preoptic area, the striohypothalamic nucleus, and the dorsomedial hypothalamic nucleus, according to the coordinates of Paxinos and Watson (1986). At more ventral levels of the plane of the horizontal slice, the anterior hypothalamic area was also part of the presynaptic inhibitory zone (Fig. 5).

GAD65 mRNA-containing neurons were found scattered throughout the hypothalamus, surrounding the PVN in the horizontal plane (Fig. 6). They were most concentrated in areas caudal to the PVN, corresponding to the dorsal hypothalamic area, and rostral to the fornix, in the medial part of the posterior bed nucleus of the stria terminalis, the striohypothalamic nucleus, and the medial preoptic area (Paxinos and Watson, 1986). These regions included the sites at which glutamate microstimulation elicited IPSPs in PVN neurons. Very few GAD mRNA-containing neurons were found within the PVN.

In the parasagittal plane, glutamate microstimulation elicited an increase in PSPs in 22 of 38 PVN neurons tested, of which 11 were putative magnocellular and 11 putative parvocellular neurons (Table 1). Glutamate microdrops evoked synaptic responses in PVN neurons when applied in three positions-caudal to the
PVN, rostral to the PVN, and at the base of the hypothalamus just dorsal to the optic chiasm (Fig. 7). Glutamate drops applied in the first position, caudal to the PVN, generated synaptic responses in the highest proportion of recorded neurons, 15 of 25 cells $(60 \%)$. Responses in five of these cells were identified positively as inhibitory. Glutamate microapplication in the second position, rostral to the PVN, elicited PSPs in 7 of 24 neurons tested (29\%), four of which also were activated by glutamate drops at the first site. The PSPs in three of these cells were identified as IPSPs. Glutamate microapplication in the third position, dorsal to the optic chiasm, elicited an increase in synaptic activity in 6 of 18 cells $(33 \%)$. The response in one of these cells was confirmed as inhibitory. Glutamate elicited a synaptic response when dropped in more than one position in a total of six neurons. Five responsive neurons (1 magnocellular and 4 parvocellular neurons) were identified immunohistochemically.

The caudal site, which provided the strongest projection to the PVN in the parasagittal plane, was located in the dorsomedial hypothalamic area. The rostral site included parts of the anterior hypothalamic area, the striohypothalamic nucleus, and the medial part of the posterior bed nucleus of the stria terminalis. The ventral site included the suprachiasmatic nucleus and part of the 


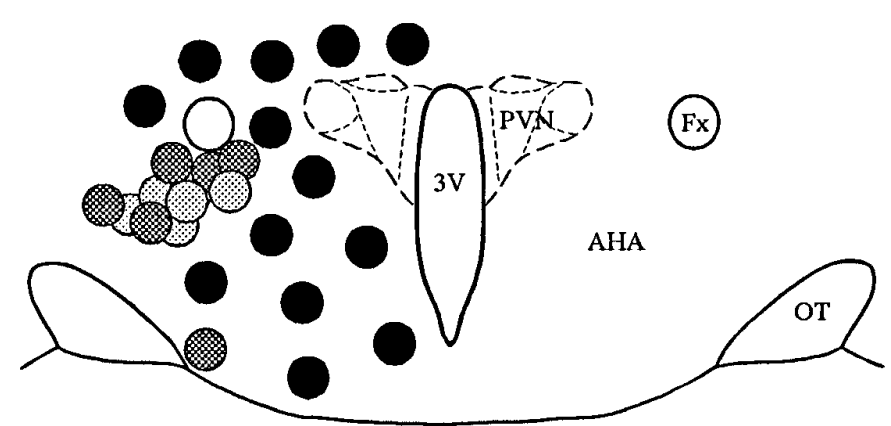

Figure 3. Topographic distribution of presynaptic active zones in the coronal slice. Glutamate microstimulation at positions lateral to the PVN and ventral to the fornix elicited an increase in PSPs recorded in PVN neurons, shown with light and dark gray circles. Each gray circle represents the site at which glutamate microstimulation elicited a synaptic response in a PVN cell. The dark gray circles represent the sites at which the glutamate-evoked synaptic responses were verified as inhibitory (see text). The microstimulation sites at which no synaptic response was recorded in PVN neurons are shown with black circles. The schematic diagram of the hypothalamus was modified from the atlas of Swanson (1992). AHA, Anterior hypothalamic area; $F x$, fornix; $O T$, optic tract; $3 V$, third ventricle.

medial preoptic area (Fig. 7), according to the atlas of Paxinos and Watson (1986).

In parasagittal sections of the hypothalamus, GAD65 mRNA was expressed in cells clustered rostroventral and caudal to the PVN (Fig. 8), corresponding to the medial preoptic and the anterior hypothalamic areas, the suprachiasmatic nucleus, and the dorsohypothalamic area (Paxinos and Watson, 1986). These regions contained the sites that responded to glutamate microdrops by generating IPSPs in PVN neurons.

\section{DISCUSSION}

\section{Glutamate microstimulation of local circuit neurons}

Glutamate microapplication has been shown to stimulate local presynaptic neurons selectively without activating axons of passage (Goodchild et al., 1982; Christian and Dudek, 1988). Glutamate microdrops applied directly to cells in and around the PVN cause depolarization and repetitive action potentials (Tasker and Dudek, 1993). Synaptic responses in PVN neurons elicited by glutamate microstimulation are mediated by actions at presynaptic somatic/dendritic receptors, because they are abolished by blockade of spike-mediated transmitter release with the voltagegated $\mathrm{Na}^{+}$channel antagonist tetrodotoxin (Tasker and Dudek, 1993). It is unlikely that the synaptic responses to glutamate microdrops in the present study were caused by actions at metabotropic glutamate receptors on GABA terminals (Forsythe and Clements, 1990), because activation of presynaptic metabotropic receptors in the supraoptic nucleus (SON) results in a significant reduction in GABA release onto magnocellular neurons (Schrader and Tasker, 1996).

\section{Glutamate-evoked synaptic responses}

We found that $42 \%$ of the magnocellular and $44 \%$ of the parvocellular neurons tested in the PVN received synaptic inputs from one or more presynaptic sites stimulated with glutamate microdrops. This estimate of the density of local synaptic inputs to PVN neurons is probably a conservative one, because many of the local synaptic connections are severed by the slicing procedure and because the glutamate microdrops were unlikely to contact all of the local presynaptic neurons in each slice. Although not all of the synaptic responses were identified positively as GABAergic, each

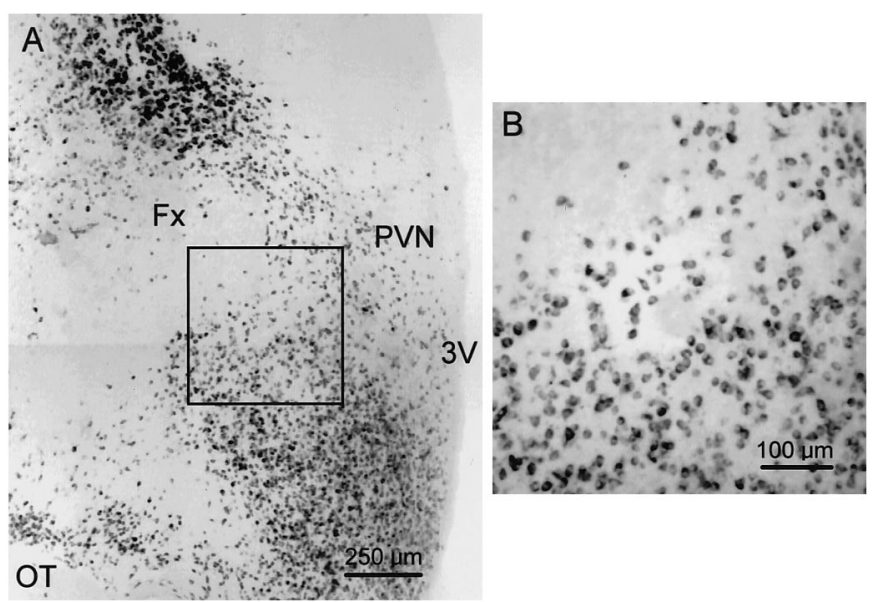

Figure 4. Distribution of GAD65 mRNA-containing neurons in the coronal plane of the hypothalamus. $A$, Low-magnification photomontage of a coronal section labeled with the GAD65 riboprobe. GAD65 mRNA was expressed in neurons concentrated in regions dorsal to the fornix $(F x)$, corresponding to the zona incerta, and ventrolateral to the PVN in the anterior hypothalamic area. Some weakly labeled neurons can be seen within the PVN, although a greater density of labeled cells was found around the ventrolateral edge of the nucleus. The hypothalamic region delineated by the box represents part of the area ventrolateral to the PVN in which glutamate microstimulation was effective at eliciting IPSPs in PVN neurons; it is shown at higher magnification in $B . O T$, Optic tract; $3 \mathrm{~V}$, third ventricle.

of the presynaptic sites in the three planes was found to send an inhibitory projection to the PVN, except for the most caudal site in the horizontal slice, which sent only a weak projection to the PVN (i.e., responses were detected in only 3 of 31 cells) and which probably corresponds to the dorsal aspect of the caudal presynaptic site in the parasagittal plane. Approximately one-third of the total synaptic responses to glutamate microdrops were confirmed as inhibitory, mediated by GABA release. This, too, is probably an underestimate of the relative density of local GABAergic inputs to PVN neurons, because many of the recordings were performed with $\mathrm{KCl}$-filled microelectrodes and synaptic responses were counted as inhibitory only if the PSPs were blocked by bicuculline, in recordings with $\mathrm{KCl}$ microelectrodes, or if they were hyperpolarizing, in patch recordings and recordings with potassium acetate microelectrodes. The amplitudes of the PSPs in most cells recorded with $\mathrm{KCl}$-filled microelectrodes were large, suggesting that they were reversed IPSPs (our unpublished observation). Thus the majority of the depolarizing PSPs recorded with $\mathrm{KCl}$ microelectrodes were likely to be reversed IPSPs.

\section{Topographic mapping of local presynaptic neurons}

Local synaptic inputs to PVN neurons were studied in three planes of section-coronal, horizontal and parasagittal-in an attempt to extrapolate a three-dimensional topography of the hypothalamic regions that concentrate presynaptic inhibitory neurons. No differences were found in the topography of presynaptic sites projecting to magnocellular or parvocellular neurons. Based on the atlas of Paxinos and Watson (1986) and that of Swanson (1992), the presynaptic inhibitory sites comprised two fairly discrete zones. The first zone coursed laterally around the PVN from its caudal limit in the dorsomedial hypothalamic nucleus, rostrally through the anterior hypothalamic area, the posterior bed nucleus of the stria terminalis, and the striohypothalamic nucleus, to its rostral limit in the medial preoptic area. A second presynaptic 


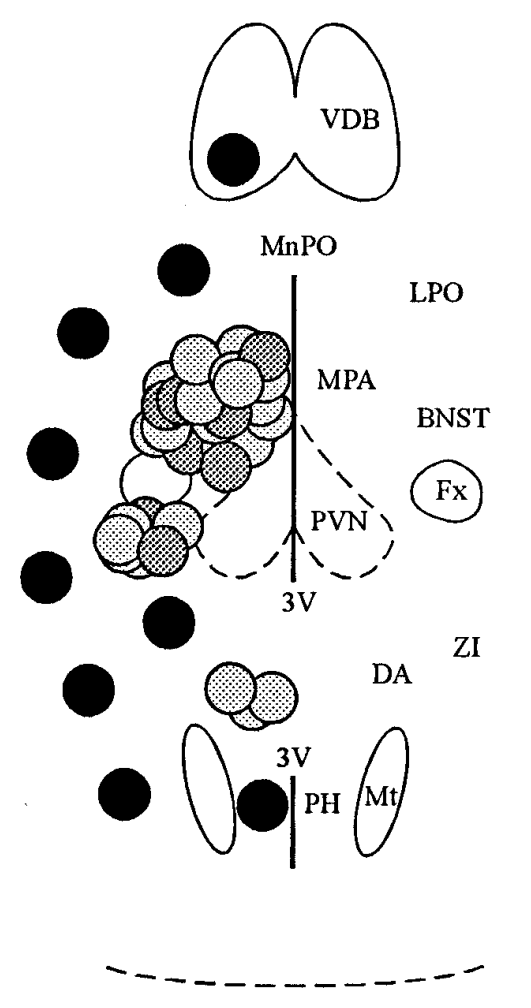

Figure 5. Topographic distribution of presynaptic active zones in the horizontal slice. Glutamate microstimulation elicited PSPs in PVN neurons when applied in three positions in the horizontal plane: rostral to the PVN and to the fornix, lateral to the PVN and caudal to the fornix, and caudal to the PVN, as shown with light and dark gray circles. Each gray circle represents the site at which glutamate microstimulation elicited a synaptic response in a PVN neuron. Sites at which glutamate microstimulation evoked synaptic responses that were confirmed as inhibitory are shown with dark gray circles. No synaptic responses were recorded with glutamate microstimulation in the locations shown with black circles. Rostral is up in this diagram. BNST, Bed nucleus of the stria terminalis; $F x$, fornix; $D A$, dorsal hypothalamic area; $L P O$, lateral preoptic area; $M n P O$, median preoptic nucleus; $M P A$, medial preoptic area; $M t$, mamillothalamic tract; $P H$, posterior hypothalamic area; $3 \mathrm{~V}$, third ventricle; $V D B$, vertical limb of the diagonal band of Broca; $Z I$, zona incerta.

zone revealed by glutamate microstimulation was located at the base of the hypothalamus just dorsal to the optic chiasm and appeared to include the suprachiasmatic nucleus. Figure 9 presents a theoretical diagram of these two zones based on the rendering in three dimensions of the topographic locations of the presynaptic sites seen in the three slice planes. The diagram is shown to provide a qualitative rendering of the extrapolated three-dimensional distribution of presynaptic GABA neurons and does not take into account quantitative differences in the density of inputs from specific sites.

These data provide an electrophysiological correlate to anatomical reports that show GABAergic projections from hypothalamic and proximal limbic areas to the PVN. The dorsomedial, anterior hypothalamic, and preoptic areas contain GABAproducing neurons (Okamura et al., 1990) (present study), and they send projections to the PVN (Tribollet and Dreifuss, 1981; Ter Horst and Luiten, 1986; Larsen et al., 1994), some of which are GABAergic (Roland and Sawchenko, 1993). The bed nucleus of the stria terminalis also concentrates GABA-producing neurons (Cullinan et al., 1993) (present study) that project to the PVN (Roland and Sawchenko, 1993). The bed nucleus, in

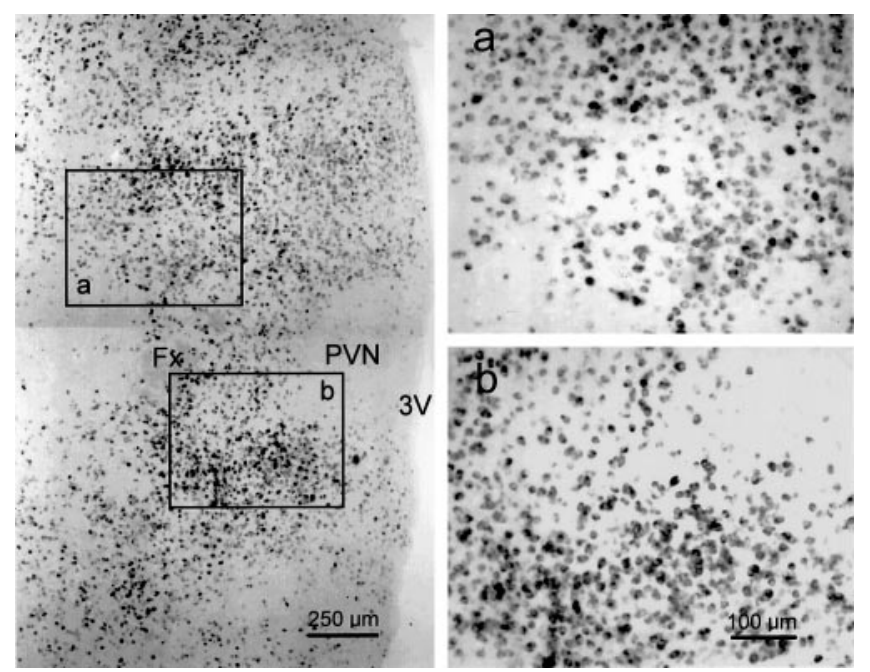

Figure 6. Distribution of GAD65 mRNA-containing neurons in the horizontal plane of the hypothalamus. Low-magnification photomontage of a horizontal section labeled with the GAD65 riboprobe (left). GAD65 mRNA is expressed in neurons scattered throughout the hypothalamus, including cells surrounding the PVN, which itself is relatively devoid of GAD65 mRNA-containing cells. The sites rostral and caudal to the fornix that were stimulated by glutamate microdrops to elicit IPSPs in PVN neurons are represented by boxes $a$ and $b$, respectively, which are shown at higher magnification to the right. The midline is to the right, and rostral is $u p$ in each photomicrograph. The calibration in $b$ pertains to both $a$ and $b$. $F x$, Fornix; $3 V$, third ventricle.

turn, seems to be an important relay in descending and ascending pathways, because it receives projections from more distal limbic structures (Weller and Smith, 1982; Cullinan et al., 1993; Arluison et al., 1994) as well as from brainstem A1 noradrenergic neurons (McKellar and Loewy, 1982; Woulfe et al., 1988). Furthermore, the bed nucleus may be part of a feedback circuit to the PVN, because it also receives peptidergic afferents from the hypothalamus (Ingram and Moos, 1992; Arluison et al., 1994). The second presynaptic zone seen in our experiments encompassed a region at the base of the hypothalamus that appeared to include the suprachiasmatic nucleus. Several studies have shown that GABA neurons exist within the suprachiasmatic nucleus (Decavel and van den Pol, 1990; Okamura et al., 1990) (present study) and that efferents from the suprachiasmatic nucleus project to the PVN (Watts et al., 1987; Hermes and Renaud, 1993; Vrang et al., 1995). This zone also may include a region dorsal to the optic chiasm that has been found to project to both the PVN and the SON (Thellier et al., 1994).

\section{Functional significance of local inhibitory inputs to PVN neurons}

Projections from the subiculum, the septum, and the amygdala terminate around the PVN and, in general, do not enter the nucleus (Silverman and Oldfield, 1984; Oldfield and Silverman, 1985; Roland and Sawchenko, 1993). The perinuclear presynaptic zone revealed by our experiments, including the dorsomedial hypothalamic and anterior hypothalamic areas as well as portions of the medial preoptic area and the bed nucleus, shows substantial overlap with the terminal fields of limbic afferents. The stimulation of limbic structures inhibits magnocellular neurosecretory cells (Negoro et al., 1973; Poulain et al., 1980; Pittman et al., 1981; Saphier and Feldman, 1987), and lesions of limbic structures or pathways disinhibit corticotropinreleasing hormone cells of the PVN (Herman et al., 1992, 1994). Because principal neurons of the subiculum and other limbic neu- 


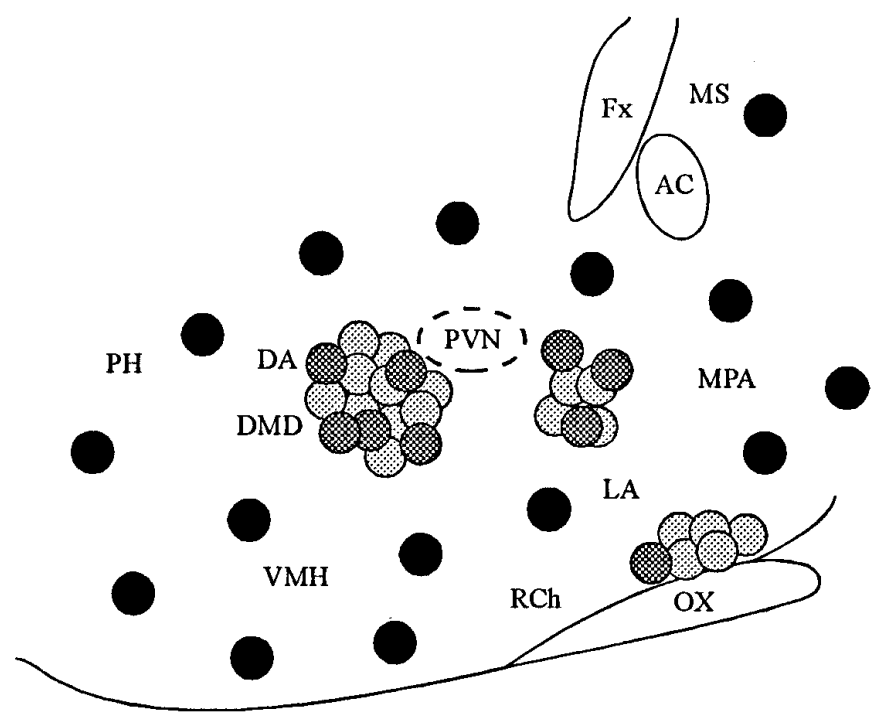

Figure 7. Topographic distribution of presynaptic active zones in the parasagittal slice. PSPs were evoked in PVN neurons with glutamate microstimulation in three positions in the parasagittal plane: caudal to the PVN, rostral to the PVN, and at the base of the hypothalamus dorsal to the optic chiasm, as shown by the light and dark gray circles. Each gray circle marks the spot at which glutamate microstimulation evoked a synaptic response in a PVN neuron. The sites at which the glutamate microdrops elicited synaptic responses identified as IPSPs are shown by the dark gray circles. The positions in which glutamate microdrops never elicited a synaptic response are designated with black circles. Rostral is to the right. $A C$, Anterior commissure; $D A$, dorsal hypothalamic area; $D M D$, dorsomedial hypothalamic nucleus; $F x$, fornix; $L A$, lateral hypothalamus; $M P A$, medial preoptic area; $M S$, medial septum; $O X$, optic chiasm; $P H$, posterior hypothalamic area; $R c h$, retrochiasmatic area; $V M H$, ventromedial hypothalamic nucleus.

rons release glutamate (Wallas and Fonnum, 1980), which generally acts as an excitatory neurotransmitter, and because limbic projections stop short of entering the PVN (Oldfield and Silverman, 1985), it is likely that these structures exert their inhibitory effects via inhibitory relay neurons located in the perinuclear zone, which feed forward to the PVN to inhibit the activity of the PVN neurosecretory cells. Our findings are consistent with, and provide a physiological substrate for, a perinuclear inhibitory zone that relays information from the limbic system to the PVN, as put forth by Roland and Sawchenko (1993).

We found electrophysiological evidence for inhibitory projections to PVN magnocellular and parvocellular neurons from an area dorsal to the optic chiasm that appeared to include the suprachiasmatic nucleus (SCN). The functional inhibitory projections from the SCN to PVN magnocellular and parvocellular neurons revealed in our experiments may mediate the diurnal rhythms of these cells and the cyclic release of PVN hormones. Further studies focusing on this circuit are required to characterize its role in neurosecretion.

How the local inhibitory projections to the PVN revealed by glutamate microstimulation might contribute to the periodic activation of PVN neurosecretory neurons is not clear. One possibility is that the local inhibitory inputs to neuroendocrine cells are tonically active and that synchronization of electrical activity arises from the lifting of this inhibitory tone simultaneously in all the cells of a given population. We have observed in the PVN, and others have reported in the SON, tonic GABA-mediated inhibitory inputs to magnocellular and parvocellular neurons (Randle et

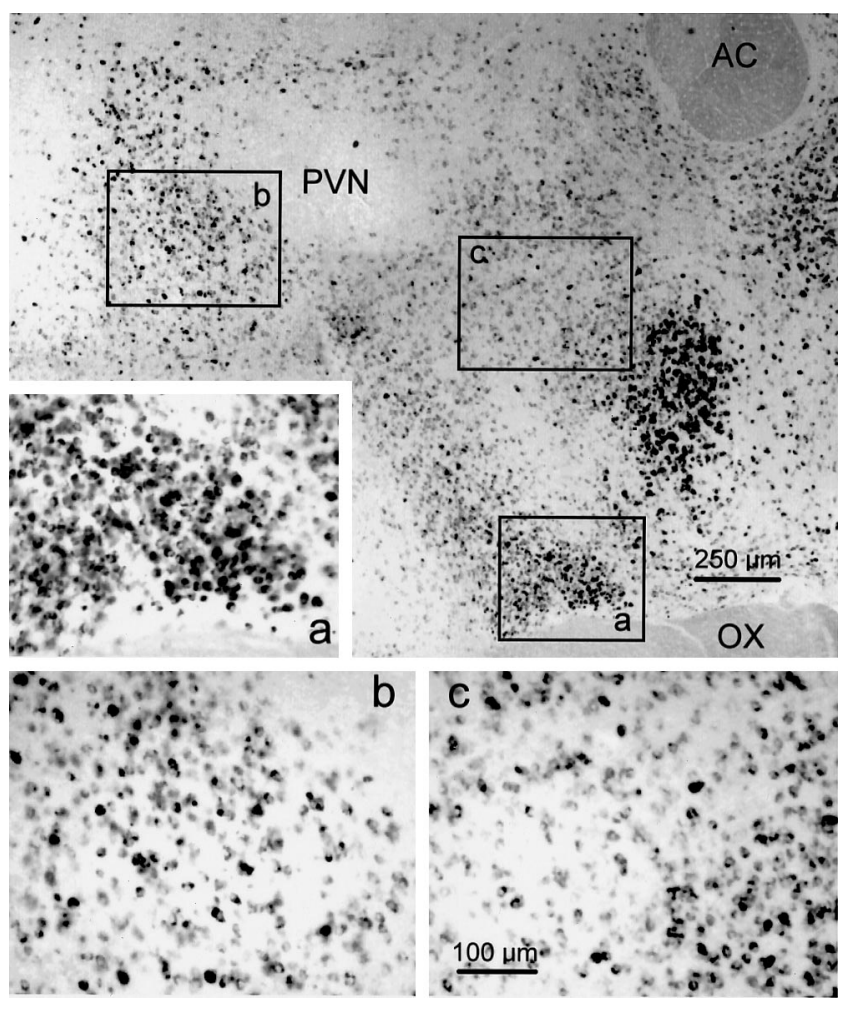

Figure 8. Distribution of GAD65 mRNA-containing cells in the parasagittal plane of the hypothalamus. Shown is a photomontage at low magnification of a parasagittal section labeled with the GAD65 riboprobe. GAD65 mRNA was expressed in cells concentrated most heavily in areas rostral to the PVN, corresponding to the medial preoptic area and dorsal to the optic chiasm $(O X)$, including the suprachiasmatic nucleus. Inset $a$, shown at higher magnification to the left, represents the ventral site at which glutamate microstimulation elicited IPSPs in PVN neurons recorded in parasagittal slices. This site had a high density of strongly labeled neurons. The other two sites responsive to glutamate microstimulation caudal and ventrorostral to the PVN are designated by boxes $b$ and $c$, respectively; these sites contained a qualitatively moderate density of GAD65 mRNA-expressing neurons and are shown at higher magnification below $(b, c)$. The second site $(b o x b)$ is located in the dorsomedial hypothalamic area. The third site (box $c$ ) includes the anterior hypothalamic and medial preoptic areas, the striohypothalamic nucleus, and the medial part of the posterior bed nucleus of the stria terminalis. Rostral is to the right. $A C$, Anterior commissure; $O X$, optic chiasm.

al., 1986; Wuarin and Dudek, 1993; Moos, 1995), but the gating role of these inputs in neuroendocrine pulsatility remains to be determined (Moos, 1995; Voisin et al., 1995). A more likely functional role of local inhibitory inputs to PVN neurons, based on the topographic correlation between local presynaptic GABA neurons and the perinuclear terminal fields of limbic afferents, is that of a modulator of cyclic electrical activity. These local inhibitory circuits might, for example, mediate the inhibitory override of neuroendocrine activity by the activation of higher brain centers such as the limbic system. Consistent with this hypothesis are studies showing that stimulation of the septum inhibits the activity of PVN and SON oxytocin neurons and reflex milk ejection (Pittman et al., 1981; Boudaba and Poulain, 1991), whereas lesion of the septum does not change the suckling-induced pulsatile release of oxytocin (Boudaba and Poulain, 1991), suggesting that the septal input to the oxytocin neuroendocrine system has a modulatory, rather than a gating, role in the pulsatility of oxytocin release. Thus, local inhibitory circuits might not be critical for the patterning of electrical activity responsible for pulsatile hormone 


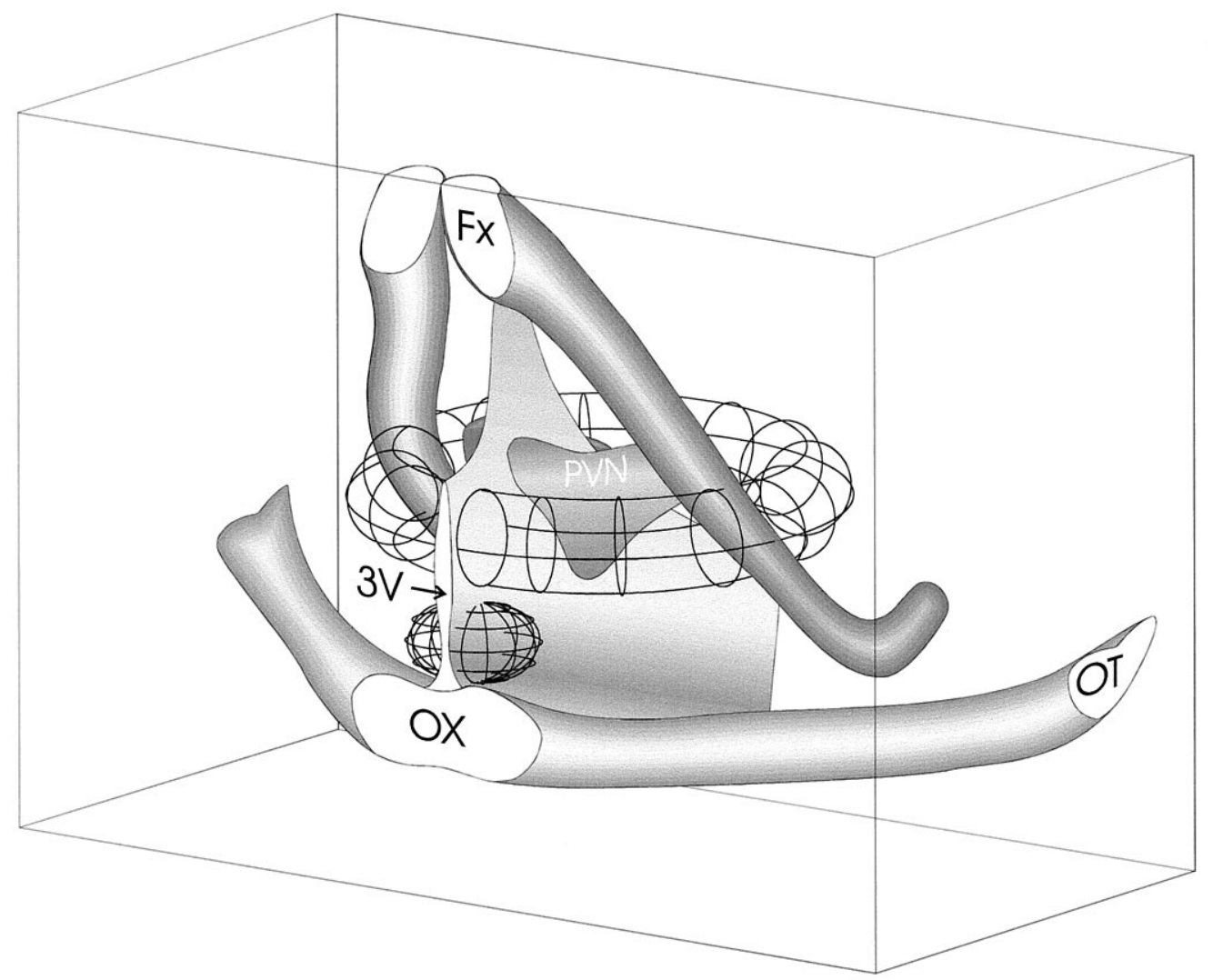

Figure 9. Three-dimensional rendering of presynaptic active zones. The topographic maps of presynaptic active sites in the coronal, horizontal, and parasagittal planes were rendered to create a qualitative schematic diagram depicting an approximated three-dimensional topography of zones concentrating PVN-projecting GABA neurons. The lateral sites together form a ring that courses ventrally and laterally around the PVN, and the ventral zone is situated just dorsal to the optic chiasm. The lateral spread of the ventral zone is unknown, because only the parasagittal plane that included the PVN was tested. Fx, Fornix; $O T$, optic tract; $O X$, optic chiasm; $3 V$, third ventricle.

release, but they may modulate these patterns on the basis of the convergence of ascending and descending sensory, emotional, and cognitive information.

\section{REFERENCES}

Altstein M, Whitnall MH, House S, Key S, Gainer H (1988) An immunochemical analysis of oxytocin and vasopressin prohormone processing in vivo. Peptides 9:87-105.

Arluison M, Brochier G, Vankova M, Leviel V, Villalobos J, Tramu G (1994) Demonstration of peptidergic afferents to the bed nucleus of the stria terminalis using local injections of colchicine. A combined immunohistochemical and retrograde tracing study. Brain Res Bull 34:319-337.

Boudaba C, Poulain DA (1991) Further evidence that the septum is not part of the main pathway of the milk ejection in the rat. J Neuroendocrinol 3:199-204.

Boudaba C, Szabó K, Tasker JG (1995) Physiological mapping of local inhibitory neurons which project to the paraventricular nucleus in rat hypothalamic slices. Soc Neurosci Abstr 21:1665.

Bourque CW (1988) Transient calcium-dependent potassium current in the magnocellular neurosecretory cells of the rat supraoptic nucleus. J Physiol (Lond) 397:331-347.

Bourque CW, Renaud LP (1990) Electrophysiology of mammalian magnocellular vasopressin and oxytocin neurosecretory neurons. Front Neuroendocrinol 11:183-212.

Christian EP, Dudek FE (1988) Characteristics of local excitatory circuits studied with glutamate microapplication in the CA3 area of rat hippocampal slices. J Neurophysiol 59:90-109.

Cullinan WE, Herman JP, Watson SJ (1993) Ventral subicular interaction with the hypothalamic paraventricular nucleus: evidence for a relay in the bed nucleus of the stria terminalis. J Comp Neurol 332:1-20.
Decavel C, van den Pol AN (1990) GABA: a dominant neurotransmitter in the hypothalamus. J Comp Neurol 302:1019-1037.

Erlander MG, Tillakaratne NJK, Feldblum N, Patel N, Tobin AJ (1991) Two genes encode distinct glutamate decarboxylases. Neuron 7:91-100. Esclapez M, Tillakaratne NJK, Tobin AJ, Houser CR (1993) Comparative localization of mRNAs encoding two forms of glutamic acid decarboxylase with nonradioactive in situ hybridization methods. J Comp Neurol 331:339-362.

Forsythe ID, Clements JD (1990) Presynaptic glutamate receptors depress excitatory monosynaptic transmission between mouse hippocampal neurones. J Physiol (Lond) 429:1-16.

Goodchild AK, Dampney RAL, Bandler R (1982) A method of evoking physiological responses by stimulation of cell bodies, but not axons of passage, within localized regions of the central nervous system. J Neurosci Methods 6:351-363.

Herman JP, Cullinan WE, Young EA, Akil H, Watson SJ (1992) Selective forebrain fiber tract lesions implicate ventral hippocampal structures in tonic regulation of paraventricular nucleus corticotropinreleasing hormone $(\mathrm{CRH})$ and arginine vasopressin (AVP) mRNA expression. Brain Res 592:228-238.

Herman JP, Cullinan WE, Watson SJ (1994) Involvement of the bed nucleus of the stria terminalis in tonic regulation of paraventricular hypothalamic CRH and AVP mRNA expression. J Neuroendocrinol 6:433-442.

Hermes MLHJ, Renaud LP (1993) Differential responses of identified rat hypothalamic paraventricular neurons to suprachiasmatic nucleus stimulation. Neuroscience 56:823-832.

Hoffman NW, Tasker JG, Dudek FE (1991) Immunohistochemical differentiation of electrophysiologically defined neuronal populations in the region of the rat hypothalamic paraventricular nucleus. J Comp Neurol 307:405-416. 
Ingram CD, Moos F (1992) Oxytocin-containing pathway to the bed nucleus of the stria terminalis of the lactating rat brain: immunocytochemical and in vitro electrophysiological evidence. Neuroscience 47:439-452.

Kiss JZ, Palkovits M, Záborsky L, Tribollet E, Szabó D, Makara GB (1983) Quantitative histological studies on the hypothalamic paraventricular nucleus in rats. II. Number of local and certain afferent nerve terminals. Brain Res 265:11-20.

Larsen PJ, Hay-Schmidt A, Mikkelsen JD (1994) Efferent connections from the lateral hypothalamic region and the lateral preoptic area to the hypothalamic paraventricular nucleus of the rat. J Comp Neurol 342:299-319.

McKellar S, Loewy AD (1982) Efferent projections of the A1 catecholamine cell group in the rat. An autoradiographic study. Brain Res 241:11-49.

Moos FC (1995) GABA-induced facilitation of the periodic bursting activity of oxytocin neurones in suckled rats. $\mathbf{J}$ Physiol (Lond) 488:103-114.

Negoro H, Visessuwan S, Holland R (1973) Inhibition and excitation of units in paraventricular nucleus after stimulation of the septum, amygdala, and neurohypophysis. Brain Res 57:479-483.

Okamura H, Abitol M, Julien JF, Dumas S, Berod A, Geffard M, Kitahama K, Bobillier P, Mallet J, Wiklund L (1990) Neurons containing messenger RNA encoding glutamate decarboxylase in rat hypothalamus demonstrated by in situ hybridization, with special emphasis on cell groups in medial preoptic area, anterior hypothalamic area, and dorsomedial hypothalamic nucleus. Neuroscience 39:675-699.

Oldfield BJ, Silverman AJ (1985) A light microscopic HRP study of limbic projections to the vasopressin-containing nuclear groups of the hypothalamus. Brain Res Bull 14:143-157.

Paxinos G, Watson C (1986) The rat brain in stereotaxic coordinates, 2nd Ed. Sydney, Australia: Academic.

Pittman QJ, Blume HW, Renaud LP (1981) Connections of the hypothalamic paraventricular nucleus with the neurohypophysis, median eminence, amygdala, lateral septum, and midbrain periaqueducal gray: an electrophysiological study in the rat. Brain Res 215:15-28.

Poulain DA, Wakerley JB (1982) Electrophysiology of hypothalamic neurones secreting oxytocin and vasopressin. Neuroscience 7:773-808.

Poulain DA, Ellendorff F, Vincent JD (1980) Septal connections with identified oxytocin and vasopressin neurons in the supraoptic nucleus of the rat. An electrophysiological investigation. Neuroscience 5:379-387.

Randle JCR, Bourque CW, Renaud LP (1986) Characterization of spontaneous and evoked inhibitory postsynaptic potentials in rat supraoptic neurosecretory neurons in vitro. J Neurophysiol 56:1703-1717.

Roland BL, Sawchenko PE (1993) Local origins of some GABAergic projections to the paraventricular and supraoptic nuclei of the hypothalamus in the rat. J Comp Neurol 332:123-143.

Saphier D, Feldman S (1987) Effects of septal and hippocampal stimuli on paraventricular nucleus neurons. Neuroscience 20:749-755.
Schrader LA, Tasker JG (1996) Presynaptic modulation by metabotropic glutamate receptors of excitatory and inhibitory synaptic inputs to hypothalamic magnocellular neurons. J Neurophysiol, in press.

Seif SM, Huellmantel AB, Platia MP, Haluszczak C, Robinson AG (1977) Isolation, radioimmunoassay, and physiologic secretion of rat neurophysin. Endocrinology 100:1317-1326.

Silverman AJ, Oldfield BJ (1984) Synaptic input to vasopressin neurons of the paraventricular nucleus (PVN). Peptides 5:139-150.

Swanson LW (1992) Brain maps. Structure of the rat brain, 1st Ed. Amsterdam: Elsevier Science.

Swanson LW, Sawchenko PE (1983) Hypothalamic integration: organization of the paraventricular and supraoptic nuclei. Annu Rev Neurosci 6:269-324.

Tasker JG (1993) Local synaptic inputs to identified neurons in the hypothalamic paraventricular nucleus. Soc Neurosci Abstr 19:157.

Tasker JG, Dudek FE (1991) Electrophysiological properties of neurones in the region of the paraventricular nucleus in slices of rat hypothalamus. J Physiol (Lond) 434:271-293.

Tasker JG, Dudek FE (1993) Local inhibitory synaptic inputs to neurones of the paraventricular nucleus in slices of rat hypothalamus. J Physiol (Lond) 469:179-192.

Ter Horst GJ, Luiten PGM (1986) The projections of the dorsomedial hypothalamic nucleus in the rat. Brain Res Bull 16:231-248.

Thellier D, Moos F, Richard PH, Stoeckel ME (1994) Evidence for connections between a discrete hypothalamic dorsochiasmatic area and the supraoptic and paraventricular nuclei. Brain Res Bull 34:261-274.

Tribollet E, Dreifuss JJ (1981) Localization of neurones projecting to the hypothalamic paraventricular nucleus area of the rat: a horseradish peroxidase study. Neuroscience 6:1315-1328.

Voisin LD, Herbison AE, Poulain DA (1995) Central inhibitory effects of muscimol and bicuculline on the milk ejection reflex in the anaesthetized rat. J Physiol (Lond) 483:211-224.

Vrang N, Larsen PJ, Møller M, Mikkelsen JD (1995) Topographical organization of the rat suprachiasmatic-paraventricular projection. J Comp Neurol 353:585-603.

Walaas I, Fonnum F (1980) Biochemical evidence for glutamate as a transmitter in the hippocampal efferents to the basal forebrain and hypothalamus in the rat brain. Neuroscience 5:1691-1698.

Watts AG, Swanson LW, Sanchez-Watts G (1987) Efferent projections of the suprachiasmatic nucleus. I. Studies using anterograde transport of phaseolus vulgaris leucoagglutinin in the rat. $J$ Comp Neurol 258:204-229.

Weller KL, Smith DA (1982) Afferent connections to the bed nucleus of the stria terminalis. Brain Res 232:255-270.

Woulfe JM, Hrycyshyn AW, Flumerfelt BA (1988) Collateral axonal projections from the A1 noradrenergic cell group to the paraventricular nucleus and bed nucleus of stria terminalis in the rat. Exp Neurol 102:121-124.

Wuarin JP, Dudek FE (1993) Patch-clamp analysis of spontaneous synaptic currents in supraoptic neuroendocrine cells of the rat hypothalamus. J Neurosci 13:2323-2331. 